2015

\title{
An ISDS Carve-Out to Support Action on Climate Change
}

Gus Van Harten

Osgoode Hall Law School of York University, gvanharten@osgoode.yorku.ca

Follow this and additional works at: http:// digitalcommons.osgoode.yorku.ca/olsrps

\section{Recommended Citation}

Van Harten, Gus, "An ISDS Carve-Out to Support Action on Climate Change" (2015). Osgoode Legal Studies Research Paper Series.

113.

http://digitalcommons.osgoode.yorku.ca/olsrps/113 
Osgoode Legal Studies Research Paper No. 38

Vol. 11/ Issue. 08/ (2015)

\title{
An ISDS Carve-out to Support Action on Climate Change
}

\author{
Gus Van Harten
}

\begin{abstract}
: investor-state dispute resolution (ISDS) lawsuits targeting climate change action by

\section{Keywords:}

Climate change, multilateral negotiations, investor-state arbitration

\section{Author(s):}

Gus Van Harten

Osgoode Hall Law School

E: gvanharten@osgoode.yorku.ca
\end{abstract}

How should a multilateral agreement on climate change include a safeguard against risks of governments? The aim of this short report is to identify language for an ISDS carve-out that is reliable and clear considering the importance of climate change action and the financial uncertainties and potential deterrent presented by ISDS for states considering such action. 


\title{
An ISDS carve-out to support action on climate change
}

\author{
Gus Van Harten ${ }^{1}$ \\ 20 September 2015
}

\section{Overview}

In this report, I discuss how a multilateral agreement on climate change could be safeguarded against the risk of investor-state dispute resolution (ISDS) claims that target climate change action. The motivation behind the report is to support, and certainly not to undermine, a multilateral climate change agreement by drawing attention to the issue of an ISDS carve-out and suggesting detailed and strong language for a carve-out.

In particular, I propose language for an ISDS carve-out that is informed by past interpretive approaches of ISDS tribunals, the importance of climate change action, and the potential deterrent that ISDS creates for governments considering such action. The suggested carve-out is as follows:

“This Article applies to any measure adopted by a Party to this Agreement and relating to the objective of stabilizing greenhouse gas concentrations in the atmosphere at a level that would prevent dangerous anthropogenic interference with the climate system or relating to any of the principles or commitments contained in Articles 3 and 4 of the United Nations Framework Convention on Climate Change of 1992.

Such a measure shall not be subject to any existing or future treaty of a Party to the extent that it allows for investor-state dispute settlement unless the treaty states specifically and precisely, with express reference to this Article and this Agreement, that this Article is overridden. For greater certainty, in the absence of such a reference in a future treaty between two or more Parties, the future

\footnotetext{
${ }^{1}$ Osgoode Hall Law School of York University; gvanharten@osgoode.yorku.ca. I am grateful to Stepan Wood for his comments on an earlier draft of this report.
} 
treaty is presumed to include in full and without qualification the first three paragraphs of this Article.

Any dispute over the scope or application of this Article shall be referred to, and fall within, the sole and exclusive jurisdiction of [specific body and process pursuant to the multilateral climate change agreement]. For greater certainty, no investor-state dispute settlement tribunal, arbitrator, body, or process has jurisdiction over any dispute related to the scope or application of this Article.

The Parties shall not agree to any future treaty that allows for investor-state dispute settlement unless the future treaty incorporates in full and without qualification the language of the first three paragraphs of this Article. The Parties shall make best efforts to renegotiate any existing treaty with a nonParty that allows for investor-state dispute settlement in order to ensure that the existing treaty incorporates in full and without qualification the language of the first three paragraphs of this Article."

This proposed language is aimed at ensuring a reliable carve-out to protect against risks of ISDS arbitration claims targeting climate change action. Some terms used in the carve-out, including "measure" and "investor-state dispute settlement" would require definition in a multilateral climate change agreement, as discussed below. If the carve-out were included in a multilateral climate change agreement, it would apply to all treaties allowing for ISDS among the states parties to that multilateral agreement.

To support its reliability, any disputes about the scope or application of the carve-out should be referred to a decision-making body that is established and acts under the auspices of the multilateral climate change agreement, not an ISDS treaty. This would avoid the risk of evasive interpretation by ISDS tribunals and allow a forum that has direct expertise and institutional commitment concerning climate change action to resolve disputes about the meaning of the carve-out. 


\section{Comments}

These comments are supported by references to other documents and publications on ISDS. The citations below are to the author's publications which in turn include more detailed discussion and extensive references to relevant data, past ISDS decisions, and secondary literature.

A. Risks posed by ISDS to climate change action

Faced with risks of uncapped financial liability due to ISDS claims, states may be deterred from implementing measures to fulfill their climate change responsibilities. In particular, ISDS poses a risk to climate change measures because:

i. Multinational companies and wealthy foreign nationals have a unique legal right and the financial capacity to bring costly ISDS claims against states without first resorting to domestic courts or tribunals (where they offer justice and are reasonably available) for violations of foreign investor rights. ${ }^{2}$ Two common themes in the hundreds of ISDS cases thus far are disputes in the resource sector and disputes relating to public health or environmental protection measures. 3

ii. Foreign investor rights are often stated ambiguously in the treaties that allow for ISDS. In turn, such rights are subject to broad discretion of ISDS tribunals to decide issues of state liability. 4 In various cases, ISDS tribunals have interpreted foreign investor rights in ways that require public compensation for general and public purpose changes to the state's regulatory framework as applied indiscriminately to all asset owners. 5

\footnotetext{
${ }^{2}$ G Van Harten, Investment Treaty Arbitration and Public Law (Oxford University Press, 2007), 110113 .

3 G Van Harten, Sovereign Choices and Sovereign Constraints: Judicial Restraint in Investment Treaty Arbitration (Oxford University Press, 2013), 82-89.

4 Van Harten, note 1 above, chapter 4 and 122-124; Van Harten, note 2 above, 45-46.

5 Van Harten, note 2 above, 52-54, 57-61, and 82-89.
} 
iii. ISDS arbitrators have broad power over public budgets due to their authority to award uncapped amounts of compensation to foreign investors. ${ }^{6}$ States have no opportunity to avoid liability after the arbitrators issue their decision. Thus, states may face an incentive to avoid climate change action in order to limit their potential liability due to ISDS claims.

To safeguard against the risk of ISDS claims that frustrate or deter climate change action, it is suggested that a multilateral climate change agreement should include a broad carve-out from all treaties that allow for ISDS arbitration. ${ }^{7}$

B. Characteristics of a reliable carve-out

\section{Application to existing and future treaties that allow for ISDS}

For existing ISDS treaties, a carve-out in a multilateral climate change agreement should be designed as a subsequent legal agreement that would take precedence over the existing ISDS treaty. That is, the multilateral climate change agreement would be a subsequent agreement between its Parties to override all of their past treaties allowing for ISDS in matters subject to the carve-out. The states would be agreeing or clarifying in the multilateral climate change agreement that their existing consents, if any, to allow ISDS claims against them simply do not apply to climate change measures.

For future ISDS treaties, the situation is more complicated. The carve-out from ISDS in a multilateral climate change agreement would need to be sufficiently specific in its prioritization of the carve-out over the Parties' consents to ISDS in any future treaty allowing for ISDS. The carve-out proposed here aims to achieve this objective by referring to existing or future treaties and by including a requirement that any other treaty, in order for it to override the carve-out, must be specific and precise on the issue and, in particular, must expressly mention the carve-out in the multilateral

\footnotetext{
${ }^{6}$ Van Harten, note 1 above, 101-109 and 145-149; Van Harten, Note 2 above, 113-114.

7 The term "measure" should be defined broadly, as it is in many investment treaties, to include "any law, regulation, procedure, requirement or practice". e.g. North American Free Trade Agreement (NAFTA), Article 201; proposed Canada-European Union Comprehensive Economic and Trade Agreement (CETA), Article X.o1.
} 
climate change agreement. The aim is not to encourage future overrides of the carveout but rather to preclude evasive interpretations by ISDS tribunals - which have, for example, regularly avoided exclusive jurisdiction clauses in contracts that appear to preclude the treaty claim ${ }^{8}$ - that would defeat the carve-out.

For greater certainty, the carve-out also includes an obligation of each Party to reproduce the carve-out in any future ISDS treaty and a clarification that any future ISDS treaty among the Parties is presumed to include the carve-out.

\section{Application as between states that are party to the climate change agreement}

A carve-out from ISDS would only apply to ISDS treaties between or among states that are Parties to the multilateral climate change agreement. For example, a bilateral investment treaty (BIT) allowing for ISDS would be covered by the carve-out if both of the states parties to the BIT were also Parties to the multilateral climate change agreement. Similarly, a trade or investment treaty that was between more than two states and that allowed for ISDS (e.g. NAFTA, the Energy Charter Treaty) would be covered by the carve-out, albeit only for those states parties to the trade or investment treaty that were also Parties to the multilateral climate change agreement and even then only with an important caveat.9

The carve-out would not apply, however, in the case of an ISDS treaty between, on the one hand, a state that is a Party to the multilateral climate change agreement and, on the other hand, a state that is not a Party. It would not apply because the ISDS treaty would not have been overridden by a subsequent agreement between the states

\footnotetext{
${ }^{8}$ Van Harten, note 2 above, 135-147.

9 The caveat arises from Article 41 of the Vienna Convention on the Law of Treaties. This Article raises a significant prospect that an ISDS tribunal - established under a trade or investment agreement with more than two states parties, in a situation where at least one of those states parties had not ratified the multilateral climate change agreement - could decide that the ISDS carve-out did not apply in all cases brought under the relevant trade or investment agreement (including cases brought by an investor of a Party to the multilateral climate change agreement against another Party to that agreement) on the basis that (a) the carve-out affected the rights of the other states parties to the trade and investment agreement that were not Party to the multilateral climate change agreement or (b) the carve-out was incompatible with the effective execution of the object and purpose of the trade or investment agreement. This is a significant weakness in the reliability of the proposed ISDS carve-out for existing trade or investment agreements that have more than two parties. The weakness would be removed if all three or more states parties to the relevant trade or investment agreement (e.g. NAFTA, the Energy Charter Treaty) were also Parties to the multilateral climate change agreement and its ISDS carve-out.
} 
parties to the ISDS treaty. In light of this weakness, in its fourth paragraph the carve out establishes binding obligations of the states parties to include the carve out in future ISDS treaties and to make best efforts to renegotiate any existing ISDS treaty with a state that is not a Party to the multilateral climate change agreement - in order to incorporate the carve-out into the existing treaty. The issue of how to enforce these negotiating obligations is left open with the expectation that they would become part of a general enforcement process in the multilateral climate change agreement.

\section{Application to the subject matter of climate change}

What is meant by "action" or "measures" on climate change? The approach adopted here is to include any measure linked to the objective, principles, or commitments of the UN Framework Convention on Climate Change, which states for example:10

"The ultimate objective of this Convention and any related legal instruments that the Conference of the Parties may adopt is to achieve, in accordance with the relevant provisions of the Convention, stabilization of greenhouse gas concentrations in the atmosphere at a level that would prevent dangerous anthropogenic interference with the climate system...."

By drawing on the language of the Framework Convention including the principles and commitments in Articles 3 and 4, the proposed carve-out is intended to apply to a wide range of state measures relating to climate change mitigation and adaptation as characterized ultimately in the Framework Convention, its other provisions and processes, and related climate change agreements.

\section{Connection between the carve-out and climate change action}

Government action on climate change can take many forms. The proposed carve-out has been framed broadly to encompass anticipated and unanticipated measures that states may adopt and thus to avoid deterring regulatory innovation.

\footnotetext{
${ }^{10}$ United Nations Framework Convention on Climate Change, Article 2.
} 
Many existing exceptions in ISDS treaties are unreliable because they use qualified language. For example, many existing ISDS exceptions apply only to state conduct that is shown to be "necessary" to achieve a regulatory aim or only where an ISDS award is shown to "prevent" the state conduct. ${ }^{11}$ This language creates significant uncertainty by leaving open the risk of unavoidable liability for the state, at the time of an ISDS award, if ISDS arbitrators decide that the state could have adopted some other measure instead of the impugned one or that the state is not prevented from adopting a measure merely because it must pay compensation for the measure.

To avoid these uncertainties, the broader term "relating to" - used in some exceptions in ISDS treaties - has been adopted in the carve-out. This language allows for wider coverage and flexibility, while still putting a limit on wholly unrelated and thus arbitrary action by states by requiring some connection between the climate change objective and the measure said to be covered by the carve-out.

\section{Application to ISDS}

The carve-out applies to any existing or future treaty "to the extent that it allows for investor-state dispute settlement". What is meant by “investor-state dispute settlement"? A multilateral climate change agreement should define this term based on the language used in existing treaties to establish states' consents to ISDS. In particular, the definition could be linked to the types of treaties that typically allow for ISDS and to the specific rules under which ISDS claims are made.

With this in mind, the following definition is proposed:

"ISDS means any proceeding arising from a claim against a state where the claim is brought pursuant to (a) a treaty concerning international trade or foreign investment and (b) any of the following arbitration rules: the ICSID Convention (also known as the ICSID rules), the ICSID additional facility rules, the UNCITRAL arbitration rules, or any other arbitration rules including any

\footnotetext{
${ }^{11}$ e.g. Agreement Between the Government of Canada and the Government of the People's Republic of China for the Promotion and Reciprocal Protection of Investments, Article 33(2).
} 
ad hoc arbitration rules and any arbitration rules agreed by the disputing parties.”

This definition aims to capture all forms of investor-state arbitration proceedings under trade and investment treaties, but not state-state or non-arbitration proceedings. Therefore, the carve-out would apply to trade and investment treaties only to the extent that they give foreign investors the unique right to bring ISDS claims. Direct state-to-state proceedings and soft forms of ISDS - i.e. mediation or conciliation - would still be permitted in order to enforce foreign investor rights. It would be possible but complex, especially for state-to-state proceedings, to broaden the carve-out so that it applied to such proceedings. The present focus is informed by the fact that the vast majority of treaty-based ISDS claims have been investor-state arbitrations.

Also, the definition would capture treaty-based investor-state arbitration but not investor-state arbitration pursuant to a state's own legislation or a contract. To capture these other forms of ISDS, clause (a) would need to be removed.

\section{e. Avoidance of circular language}

Some ISDS treaties contain exceptions with circular language that limits or defeats the exception. For example, an exception may be limited to measures said to be "otherwise consistent with" the ISDS treaty. ${ }^{12}$ This language clearly undermines the exception and should be avoided in a carve-out for climate change action.

\section{g. Disputes over scope of the carve-out}

An important aspect of the uncertainty of state liabilities due to ISDS is the authority of ISDS tribunals to interpret ISDS exceptions narrowly. Various cases indicate this tendency of ISDS arbitrators. ${ }^{13}$

\footnotetext{
${ }^{12}$ e.g. NAFTA, note 6 above, Article 1114.
}

13 Van Harten, note 2 above, 66-68. 
With this in mind, it is suggested that disputes over the applicability of a climate change carve-out should be referred to a decision-making body that is established under the auspices of a multilateral climate change agreement rather than an ISDS treaty. Such a body would have greater expertise and institutional commitment to ensure that the carve-out was interpreted to cover all forms of action reasonably aimed at climate change mitigation or adaptation. By locating this interpretive authority in a single body, uncertainties about varying or conflicting interpretations among diverse ISDS tribunals would also be avoided. ${ }^{14}$

The language in the third paragraph of the carve-out aims to protect the exclusive jurisdiction of this body under the multilateral climate change agreement. The language is detailed and legalistic due to ISDS tribunals' past record of taking jurisdiction over ISDS disputes even in the face of, for example, an exclusive jurisdiction clause in a related contract or a waiting period or fork-in-the-road clause in an ISDS treaty.15

Beyond these points, questions about the body and process that should be used to resolve disputes about the ISDS carve-out are more a matter for experts in the Framework Convention on Climate Change than for ISDS experts.

14 G. Van Harten, "Arbitrator Behaviour in Asymmetrical Adjudication: An Empirical Study of Investment Treaty Arbitration” (2012) 50 Osgoode Hall Law Journal 211, 237 and 245 (documenting conflicting approaches by tribunals to, e.g., the ambiguous foreign investor right to "most-favourednation treatment').

15 Van Harten, note 2 above, 135-150. 